\title{
PENYULUHAN TENTANG SISTEM PEMBIAYAAN MUDHARABAH BAGI PENGUSAHA PEMULA DI LINGKUNGAN GRISAK KELURAHAN KEKALIK JAYA
}

\author{
Muhammad Irwan \\ Fakultas Ekonomi dan Bisnis Universitas Mataram \\ dae.wan65@yahoo.com \\ Titiek Herwanti. \\ Fakultas Ekonomi dan Bisnis Universitas Mataram \\ titiekherwanti2@gmail.com \\ Siti Maryam \\ Fakultas Ekonomi dan Bisnis Universitas Mataram \\ maryamnanang@gmail.com

\section{Eka Agustiani} \\ Fakultas Ekonomi dan Bisnis Universitas Mataram \\ ekaagustiani27@gmail.com
}

\section{Article History:}

Received: 31 Mei 2021

Revised: 2 Juni 2021

Accepted: 6 Juni 2021

DOI:

10.29303/abdimassangkabi ra.v1i2.36

\begin{abstract}
Abstrak: Tujuan kegiatan Pengabdian Kepada Masyarakat ini adalah: (a) Memberikan pemahaman dan pengetahuan kepada para masyarakat khususnya pengusaha pemula tentang sistem pembiayaan mudharabah; (b) Memberikan pemahaman tentang cara-cara pembagian bagi hasil dalam sistem pembiayaan mudharabah; (c) Memberikan tambahan bantuan modal untuk pengembangan usaha dan dapat dimanfaatkan oleh pengusaha pemula yang belum dan memiliki modal yang masih terbatas; (d) Membentuk kepengurusan wadah yang mengelola modal usaha yang dapat dimanfaatkan oleh pengusaha pemula dalam menjalankan usahanya.

Untuk mencapai tujuan tersebut, solusi yang dilakukan adalah (a) Memberikan pemahaman dan pengetahuan tentang sistem pembiayaan mudharabah melalui kegiatan penyuluhan; (b) Memberikan contoh-contoh perhitungan tengan cara bagi hasil antara pihak peminjam dengan pihak yang memberi pinjaman; (c) Memberi suntikan modal untuk melengkapi modal usaha yang telah ada untuk menambah pengusaha pemula memanfaatkan dana tersebut sesuai dengan kesepakatan yang telah dimusyawarahkan.

Kegiatan ini dapat dikatakan berjalan baik dan
\end{abstract}


berhasil dilihat dari beberapa indikator yaitu: (a) Kehadiran peserta yang hadir melebihi setengah dari syarat minimum, yang dihadiri oleh peserta baik laki-laki dan perempuan, (c) Diskusi dan tanya jawab yang memberikan gambaran tentang permasalahan yang dihadapi peserta terutama berkenaan dengan makna, manfaat dan cara pembagian hasi keuntungan dengan skim mudharabah, (d) Telah terbentuk susunan kepengurusan Organisasi usaha pengusaha pemula yang mengelola modal untuk dimanfaatkan oleh pengusaha pemula.

Saran yang berkenaan dengan kegiatan ini adalah (a) Tim harus menindaklanjuti keinginan peserta untuk memberikan pelatihan dan praktek sistem mudharabah secara khusus sehingga peserta atau masyarakat semakin tertarik untuk menjalankan usaha dengan sistem mudharabah; (b) Disarankan kepada peserta dan pengelola lembaga yang ada untuk melakukan sosialisasi pada tokoh-tokoh masyarakat tentang keberadaan lembaga yang terbentuk sehingga mendorong masyarakat untuk menanamkan modalnya pada lembaga tersebut; (c) Penyajian dapat dikembangkan dalam bentuk pendidikan seperti mempraktekkan langkah-langkah memulai usaha dengan sistem mudharabah dan modal pendukungnya.

Kata Kunci: Pengusaha Pemula, Pengelolaan, Pembiayaan, Mudharabah

\section{PENDAHULUAN}

Manusia menjalani kehidupannya dituntut untuk memenuhi berbagai kebutuhan terutama kebutuhan pokok. Untuk mewujudkan kebutuhannya tersebut manusia harus melakukan aktivitas dengan bekerja sesuai dengan keahlian dan kemampuannya. Banyak jenis pekerjaan yang dapat dilakukan oleh manusia salah satunya berdagang atau berbisnis. Dari berdagang dan berbisnis ini manusia akan memperoleh pendapatan dan penghasilan berupa harta benda. Dalam menjalankan aktivitas usahanya, manusia dihadapkan oleh berbagai kendala yang membutuhkan pengorbanan untuk dapat keluar dari kendala tersebut.

Dalam melakukan aktivitas usaha atau bisnis, seorang pengusaha atau wiraswastawan harus mengedepankan nilai- nilai etika bisnis. Etika bisnis adalah penerapan etika secara umum terhadap prilaku bisnis (Hamali, dkk, 2017). Usaha berdagang atau bisnis membutuhkan beberapa persyaratan di antaranya modal baik berupa modal tetap maupun modal lancar. Berkenaan dengan modal lancar, para pengusaha 
atau pebisnis memiliki keterbatasan dan jumlahnya relatif kecil, umumnyya menggunakan modal sendiri sehingga berdampak pada maju mundurnya usaha dan bisnis yang dilakukan. Oleh karenanya, banyak lembaga-lembaga keuangan konvensional dan syariah baik bank maupun non bank berupaya untuk membantu para pengusaha atau pebisnis dengan menawarakan berbagai produk - produk untuk memberikan pinjaman modal usaha kepada pengusaha.

Perbankan syariah yang tengah berkembang saat sekarang memiliki produk usaha berupa penghimpunan, pembiayaan dan jasa dengan skim yang berbeda-beda. Produk-produk tersebut masih banyak belum diketahui dan dipahami oleh masyarakat umum. Di antara berbagai skim yang ada adalah skim mudharabah yang tergolong dalam skim kerja sama dengan prinsip bagi hasil. Produk ini bagi kalangan tertentu sudah berhasabat dan telah melakukan transaksi dengan memanfaatkan skim ini. Namum masih banyak masyarakat yang belum memahami dan mengetahui prinsip kerja dari sistem mudharabah.

Lingkungan Grisak Kelurahan Kekalik Jaya Kecamatan Sekarbela Kota Mataram merupakan salah satu sentra industri kecil/Rumah Tangga Tahu Tempe yang berada di Kota Mataram. Di samping usaha ini, seiring dengan kemajuan teknologi informasi dan berkembangnya area-area di sekitar lingkungan Grisak yang dijadikan usaha bisnis berdampak pada perkembangan masyarakat yang berada di lingkungan tersebut. Di lokasi ini terdapat potensi pemuda - pemudi yang melakukan aktivitas usaha baik berhubungan langsung dengan produksi Tahu Tempe maupun aktivitas - aktivitas usaha lainnya. Terdapat masyarakat terutama pemuda setempat melakukan usaha bisnis dengan berbagai macam usaha berdagang yang bertindak sebagai pengusaha pemula. Banyak permasalahan yang dihadapi oleh pengusaha pemula di antaranya pengalaman yang masih kurang dan keterbatasan modal usaha.

Kegiatan tim pengabdian pada periode yang lalu telah memberikan pengetahuan dan pemahaman kepada pengusaha pemula tentang pemanfaatan modal berbasis syariah dalam menjalani usahanya. Permasalahan yang dihadapi adalah masih relatif kurangnya pengetahuan dan pemahaman mereka tentang tatacara bagi hasil terhadap besarnya modal yang dipinjam pada lembaga keuanga non bank yang sudah ada. Lembaga ini masih bersifat informal dan dalam melaksanakan kegiatannya masih didasarkan pada kesepakatan dan keikhlasan dari peminjam untuk menambah modal yang ada.

Berkenaan dengan permasalahan tersebut, maka pelaku aktivitas usaha sangat perlu untuk diberikan ilmu pengetahuan berkenaan dengan sistem bagi hasil dengan skim mudharabah. Ilmu pengetahuan dapat diberikan melalui bentuk penyuluhan terutama sekali tertuju pada pelaku usaha pemula. Hal ini dimaksudkan agar pelaku usaha pemula dapat mengetahui dari awal seluk beluk yang berkenaan dengan usaha termasuk 
cara memperoleh dan mengembalikan pinjaman tersebut. Dengan adanya informasi ini akan membantu pelaku usaha pemula untuk dapat memperoleh modal usaha sekaligus mengembalikannya agar proses usaha baik lembaga pemberi pinjaman maupun pengusaha pemula yang melakukan pinjaman dapat berjalan dan berkembang sesuai dengan harapan.

Permasalahan yang dihadapi oleh mitra adalah Modal usaha yang dimiliki oleh pelaku usaha pemula masih terbatas yang berdampak relatif lambannya perkembangan usaha; Keterbatasan informasi yang berkenaan dengan cara menghitung sistem bagi hasil dengan menggunakan sistem mudharabah dan Belum berfungsinya lembaga keuangan sejenis koperasi yang berbasis syariah secara optimal untuk menjamin kesinambungan modal usaha ketika dibutuhkan.

\section{METODE PELAKSANAAN}

Permasalahan yang dihadapi oleh mitra dapat dipecahkan dengan melakukan kegiatan Pengabdian Kepada Masyarakat dalam bentuk kemitraan. Kegiatan yang dilakukan adalah memberikan penyuluhan dan pengetahuan tentang cara-cara menggunakan prinsip bagi hasil dengan skim mudharabah. Beberapa tahapan yang berkenaan dengan kegiatan ini adalah tahap persiapan, Pelaksaanaan, pembinaan dan pendampingan hingga berjalannya lembaga keuangan non bank yang dibentuk.

\section{E. Tahap Persiapan}

Tahap persiapan meliputi kegiatan yang berkenaan dengan pelaksanaan yang akan dilakukan oleh tim pengabdian kepada masyarakat mulai dari perencanaan, penentuan waktu pelaksanaan, jumlah peserta hingga pelaksanaan penyuluhan. Langkah awal yang dilakukan adalah menghubungi kepala lingkungan dan tokoh pemuda, pengusaha pemula untuk melakukan identifikasi peserta yang relevan dengan kegiatan ini.

\section{F. Tahap Pelaksanaan}

Tahap pelaksanaan merupakan waktu diadakannya kegiatan penyuluhan yang telah ditentukan didasarkan pada kesepakatan dengan kepala lingkungan dan tokoh pemuda serta pengusaha pemula baik berkenaan dengan waktu maupun tempat pelaksanaan. Dalam tahap ini dilakukan tatap muka dengan peserta yang diawali dengan memberikan materi-materi dengan metode ceramah yang berkaitan dengan pemanfaatan dan pengelolaan modal usaha berbasis syariah. Selanjutnya dilakukan diskusi berkenaan dengan materi maupun permasalahanpermasalahan yang dihadapi baik pada waktu awal maupun dalam menjalankan usaha. 
Masyarakat yang dijadikan sasaran dari kegiatan penyuluhan ini adalah penduduk yang berada di Lingkungan Gerisak yang telah memali usaha berdagang dalam waktu yang tidak relatif lama (kurang dari 2 tahun). Namun demikian, diberikan peluang dan kesempatan pedagang lainnya serta pemuda-pemuda yang ingin memulai usaha tatkala berhadapan dengan pemenuhan modal usaha. Jumlah peserta yang diharapkan dan direncakanan akan mengikuti kegiatan penyuluhan ini maksimal sebanak 30 orang dengan tidak membatasi jenis kelamin.

\section{G. Tahap Pembinaan dan Pendampingan}

Tahap pembinaan dan pendampingan merupakan tahap tim pengabdian melakukan pembinaan dan pendampingan terhadap lembaga keuangan non bank (sejenis koperasi berbasis syariah) yang sudah dibentuk dengan menetapkan petugas yang bertanggung jawab terhadap jalannya lembaga tersebut. Penanggung jawab ditunjuk berdasarkan kesapakatan bersama di antara peserta.

\section{HASIL DAN PEMBAHASAN}

\section{A. Waktu Pelaksanaan}

Kegiatan ini dilaksanakan pada hari Senin, 20 September 2020 dimulai pada jam 20.000 (ba'da sholat Isya) hingga selesai. Kegiatan penyuluhan dihadiri oleh sebanyak 20 peserta baik berjenis kelamin laki-laki maupun perempuan. Sebahagian besar peserta adalah bekerja sebagai pengusaha pada berbagai jenis usaha seperti berjualan di kios, menjual minumanminuman ringan sejenis kopi, menjual tempe, menjual pulsa dan lainnya. Latar belakang pendidikan peserta bervariatif mulai dari SD, SMP, SMA/SMK, D3 dan S1. Seorang peserta tamat SMK bersama beberapa teman lainnya memulai usaha minuman dan manakan ringan pada pertengahan masa pandemi Covid-19 dan dilakukan pada malam hari dengan memanfaatkan tempat/halaman warga setempat yang memberikan ijin untuk dilakukan usaha.

Kegiatan penyuluhan diawali oleh kata pengantar dari koordinator yang telah ditunjuk oleh tim yang menjelaskan maksud dan tujuan pelaksanaan kegiatan ini. Selanjutnya tim melalui ketua tim pengabdian menyampaikan materi dengan metode ceramah yang menggambarkan secara umum mengenai materi kegiatan yang berkenaan dengan aktivitas usaha dengan memanfaatkan modal yang sudah tersedia. Setelah ketua tim menyampaikan materi secara umum lebih kurang 30 menit, kegiatan dilanjutkan dengan diskusi, untuk menggali informasi dan mengetahui permasalahan yang 


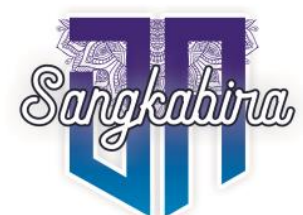

Vol. 1, No. 2, Juni 2021

dihadapi selama melalukan aktivitas usaha. Pada umumnya peserta belum mendengar istilah-istilah yang disampaikan oleh tim dan secara utuh belum bisa dipahami. Tim telah menjelaskan meski hanya sebatas metode berceramah.

Beberapa pertanyaan yang diajukan oleh peserta berkenaan dengan permasalahan yang dihadapi adalah :

1. Ibu Miskiah, sebagai pengusaha kedelai untuk membuat tempe dihadapkan oleh seringnya konsumen yang menunda pembayaran utangnya, padahal yang bersangkutan juga berutang pada pengusaha kedelai.

Menghadapi kondisi yang demikian, tim memberikan arahan kalau bisa sistem jual beli dapat dilakukan secara tunai, meskipun dengan berdagang dengan pembayaran ditunda (berutang) diperbolehkan dalam agama Islam. Karena ditengah kondisi pandemi Covid-19 ini aktivitas ekonomi mengalami kelesuan, maka sistem berdagang dengan berutang menjadi masalah bagi orang yang tidak memiliki penghasilan tetap. Demikian halnya kepada pengutang, diingatkan agar berusaha membayar hutang dengan secepatnya karena dapat berdampak negatif terhadap perkembangan usaha.

2. Ibu Makni yang sehari-hari menjajakan usaha di Sekolah Dasar di sekitar tempat tinggalnya sekarang tidak bisa lagi menjajakan dagangannya karena sekolah ditutup. Dia menanyakan bagaimana cara memperoleh modal dengan sistem ini. Dia ingin berdagang kerupuk tempe yang akan dijual di sekitar tempat tinggalnya pula.

Tim memberikan solusi supaya bergabung dalam paguyuban pengusaha pemula ini yang telah memiliki modal untuk dipinjam dengan besaran tertentu dengan sistem yang telah disepakati bersama. Sistem peminjaman tanpa bunga telah dijalankan, dan akan memperoleh kemudahan dalam memperoleh pinjaman modal yang dibutuhkan.

3. Rifki, seorang remaja yang baru selesai menamatkan sekolah pada salah satu SMKN di Kota Mataram bersama temannya membuka usaha menjual minuman seperti kopi dan teh hangat manis yang berlokasi di pinggir jalan depan halaman rumah warga. Penjualan dengan menggunakan meja dan jika hujan datang basah dan usaha tutup. Hal yang pertama adalah bagaimana memperoleh modal dan memperbesar modal usaha dan memperoleh rombong untuk menghindari hujan. Modal yang dipergunakan sekarang adalah pemberian pamannya yang harus 
dikembalikan tanpa memberi batasan waktu pengembalian dan hanya cukup untuk membeli bahan baku.

Mengatasi hal demikian tim menjawab bahwa untuk memperoleh dan mengembangkan modal usaha lihat dan evaluasi dulu perkembangan usaha yang tengah berjalan. Jika berjalan dengan baik dan terus bertambah pembelinya, makau upaya yang dilakukan pertama adalah membuat atau membeli rombong. Modal yang dipergunakan boleh mendekati kembali paman agar memberi tambahan modal untuk membeli rombong baru dipikirkan untuk membeli terop.
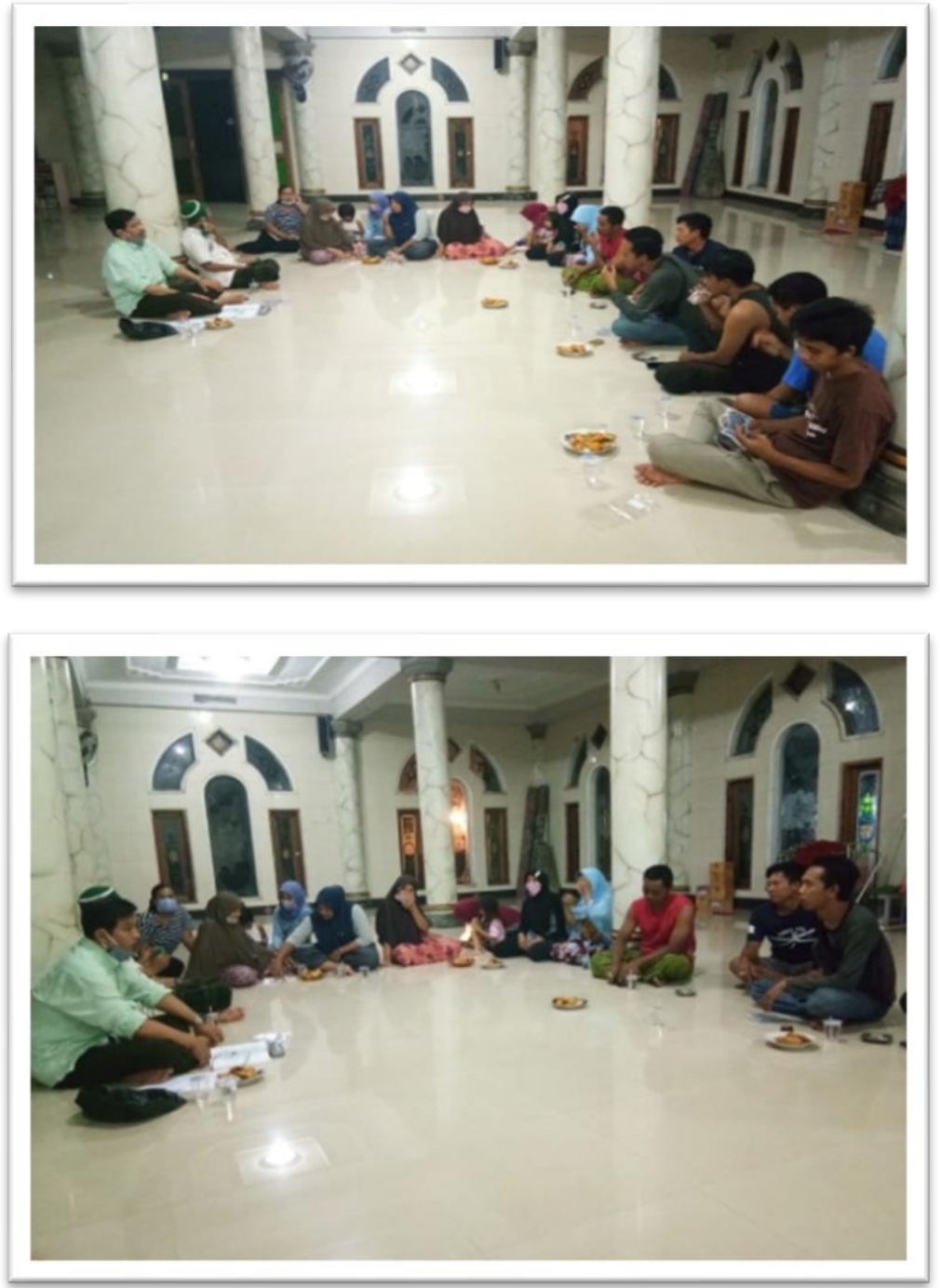


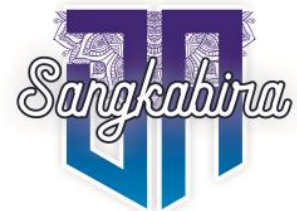

Vol. 1, No. 2, Juni 2021

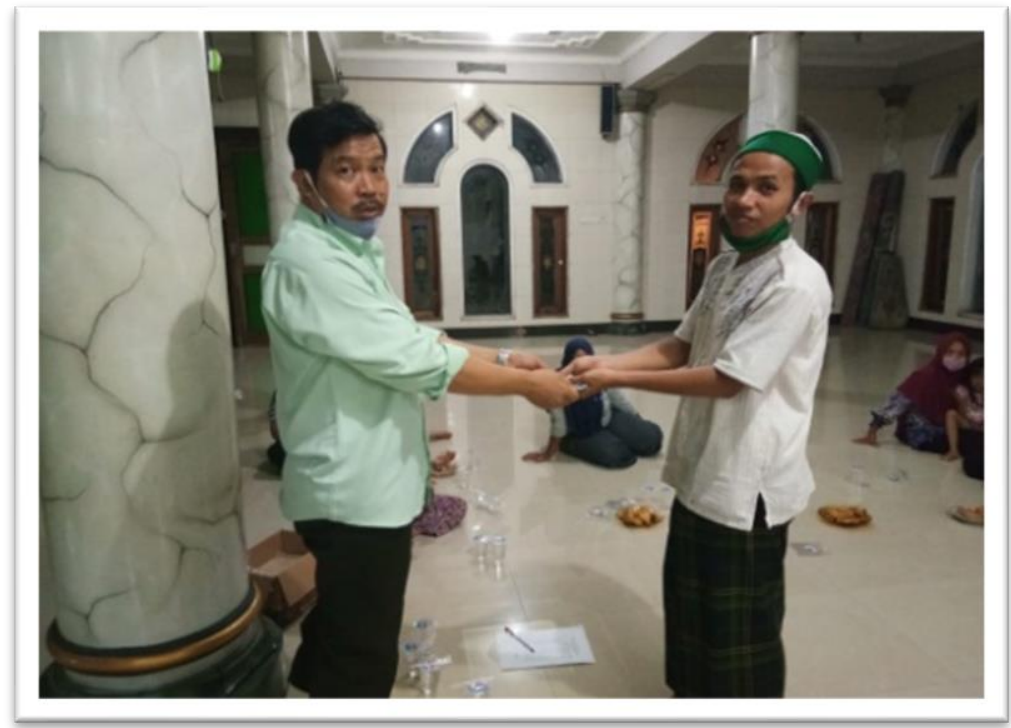

Materi yang disampaikan melalui metode ceramah telah menambah wawasan dan pengetahuan peserta berkenaan sistem mudharabah meskipun baru mendengar istilah ini. Pada waktu acara diskusi dan tanya jawab, peserta memberikan saran sekaligus harapan terhadap kegiatan ini. Beberapa pertanyaan dari peserta dan merupakan permasalahan yang dihadapi peserta dapat dihimpun sebagai berikut :

9. Peserta masih awam dalam memahami dan mengetahui tentang sistem-sistem pembiayaan berbasis syaiah salah satunya dalah sistem mudharabah.

10. Kendala utama yang dihadapi oleh peserta yang akan memulai dan sudah berusaha adalah keterbatasan modal usahan terutama sekali modal memulai dan selama menjalani usaha ketika ingin melakukan dan mengembangkan diversifikasi usaha.

11. Ada keinginan untuk mengembangkan usaha Tahu/Tempe sebagai produk yang berbasis usaha rumah tangga dengan melakukan inovasi, tetapi dihadapkan dengan kendala pengetahuan dan keterampilan yang terbatas tentang hal tersebut.

12. Kesulitan berhubungan dengan lembaga keuangan formal karena tidak dapat memenuhi persyaratan yang ditetapkan.

13. Dibutuhkan lembaga keuangan sejenis koperasi yang dapat menjembatani mereka terhadap kebutuhan modal dan kebutuhan lainnya. Dengan lembaga tersebut peserta dapat memperoleh bantuan modal baik untuk awal usaha maupun ketika usaha sudah berjalan.

14. Keterbatasan tempat untuk membuka usaha dan belum memiliki tempat usaha (rombong) yang dapat melindungi bahan dan barang yang dijual dari hal-hal yang tidak higienis.

Berdasarkan pertanyaan dan identifikasi permasalahan tersebut, tim memberikan penjelasan secara umum terutama yang berkenaan dengan keberadaan lembaga keuangan non bank sejenis koperasi yang 
menerapkan perinsip syariah. Berkenaan dengan hal ini, peserta sangat tertarik dengan paparan yang disampaikan tim, dan dibutuhkan pertemuan lebih lanjut untuk membentuk sekaligus menyusun kepengurusan koperasi berbasis syariah tersebut.

\section{Pengelolaan Modal Usaha}

Modal usaha awal bagi pengusaha pemula maupun tambahan moodal bagi pengusaha yang sudah menjalani usaha sangat diperlukan untuk keberlangsungan usaha. Sebelumnya, beberapa peserta telah memanfaatkan dana pinjaman yang berasal dari pengelola dana pinjaman yang merupakan bentukan dari ketua tim penyuluhan ini. Pengelolaan keuangan ini akan menjadi cikal bakal hadirnya lembaga keuangan syariah, baik dalam bentuk lembaga pinjaman atau koperasi syariah. Dana awal yang telah dimiliki baru mencapai Rp 4.000.000,- yang berasal dari sumbangan beberapa orang yang dipercayakan kepada ketua tim pengabdian ini sebesar Rp 1.250.000,- dan bantuan tim pengabdian sebelumnya berjumlah $\mathrm{Rp} 1.750 .000$,- dan telah digulirkan secara syariah. Melalui kegiatian in Tim penyuluhan juga memberikan suntikan modal untuk menambah modal usaha pada kegiatan ini sebesar Rp 750.000,(tujuh ratus lima puluh ribu rupiah),- yang dapat dimanfaatkan oleh peserta yang ingin memulai usaha atau menambah modal usaha yang sudah berjalan.

Adanya tambahan dana bantuan modal ini, diharapkan peserta dapat memanfaatkannya untuk modal awal usaha atau untuk melakukan diversifikasi usaha bagi yang telah berusaha. Hasil pengakuan peserta bahwa dengan memanfaatkan modal ini, merasa terbantu dan dapat melakukan diversfikasi usaha meskipun masih dalam jumlah yang relatif kecil, disesuaikan dengan besarnya modal pinjaman. Hal ini akan berlangsung secara bergilir, peserta akan memperoleh kesempatan yang sama menikmati dana pinjaman yang ada. Secara perlahan modal akan terus bertambah seiring dengan adanya bantuan tambahan modal dari peserta yang memanfaatkan modal pinjaman tersebut.

Pengelolaan modal usaha dapat dilakukan dengan memberikan pinjaman secara berkala kepada pedagang yang waktunya ditentukan berdasarkan hasil kesepakatan (akad) dari pihak pemberi modal dengan pihak penerima modal. Pengelolaan modal usaha didasarkan pada rasa saling percaya, rasa memiliki, rasa ingin menuju kearah yang lebih maju, dan rasa tanggung jawab bersama. Hal ini didasari pada prinsip saling tolong menolong, saling memberi dan menambah modal usaha sesuai dengan ketulusan dan keikhlasan masing-masing peminjam modal usaha.

Alur pemberian dan pengembalian modal usaha dapat digambarkan sebagai berikut : 


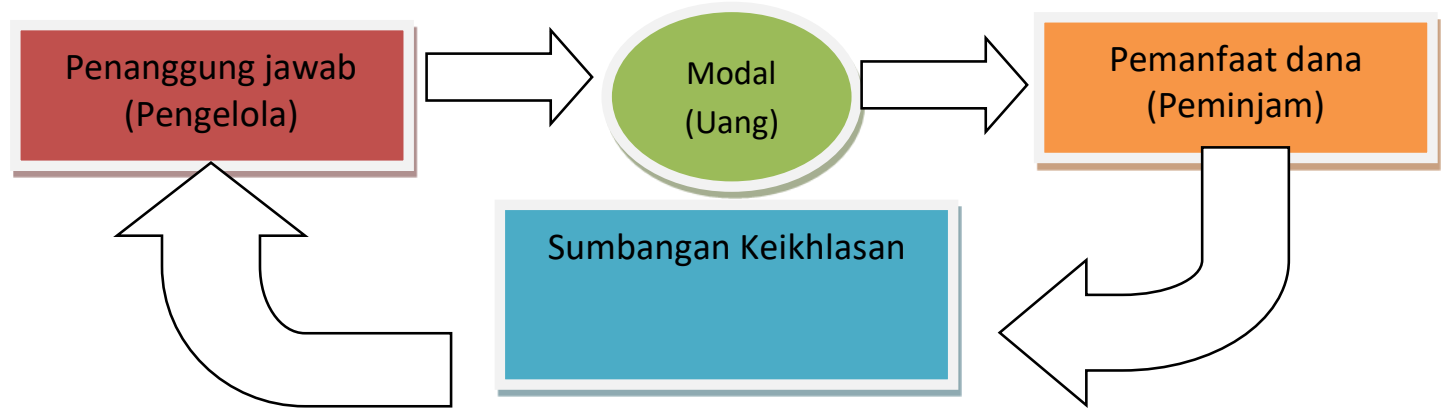

Sistem yang disepakati :

6. Pengelola memberikan sejumlah uang untuk modal usaha atau menambah modal kepada peminjam, sesuai dengan kebutuhan peminjam yang berpedoman pada syarat dan ketentuan yang berlaku.

7. Persyaratan yang harus dilakukan oleh peminjam adalah membuat pernyataan bahwa modal yang dipinjam semata-mata digunakan untuk modal atau mengembangkan usaha dan tidak boleh dimanfaatkan untuk kepentingan lain.

8. Penyerahan tambahan modal dilakukan pada waktu masa pinjaman berakhir yang disepakati paling lama 10 kali angsuran.

9. Peminjam mengembalikan modal dengan cara angsuran yang besarnya sesuai dengan keikhlasan dan berikrar untuk menambah modal dan bukan sebagai bunga.

10. Tidak ada paksaan kepada peserta untuk menambah modal yang sudah ada, melainkan berdasarkan keikhlasannya.

11. Pengelola tidak mengenakan denda bila peminjam belum mampu membayar pada salah satu priode bulan pengembalian.

12. Jika modal telah berkembang baik berasal dari keikhlasan dari peminjam maupun ada sumbangan dari pihak lain yang menambah modal, sistem dengan ikhlas ini akan dirubah dengan sistem mudharabah atau bagi hasil.

\section{Pembentukan Pengurus (Pengelola) Paguyuban Usaha}

Penyampaian materi yang disampaikan ketua tim secara umum disertai dengan diskusi telah menimbulkan semangat dari peserta untuk menindak lanjutan usaha yang masih dikelola secara individu oleh personal yang ditunjukan oleh motivator usaha ini. Berdasarkan hasil diskusi, supaya modal usaha dapat berjalan dengan baik, dan sebagai milik bersama, maka harus dikelola secara profesional secara kelembagaan. Oleh karenanya, pada kegiatan penyuluhan ini telah berhasil dibentuk suatu lembaga yang diberina nama "PAGUYUBAN USAHA PEMULA AL-MUKHLISIN LINGKUNGAN GRISAK".

Tindak lanjut terbentuknya nama tersebut, peserta yang hadir secara mufakat menunjukan beberapa nama yang dipercayai untuk mengelola 
lembaga ini yang susunan kepengurusannya terlampir. Dengan terbentuknya kepengurusan, maka aktivitas usaha ini untuk sementara masih bersifat informal dan pada saatnya nanti akan berubah menjadi usaha formal bahkan diharapkan akan terbentuk sebuah koperasi sebagaimana yang telah diniatkan dan direncanakan sebelumnya. Karena adanya berbagai kendala, maka untuk sementara Koperasi Syariah yang berbasis masjid belum dapat diwujudkan.

\section{KESIMPULAN DAN SARAN}

\section{A. Simpulan}

Berdasarkan hasil pelaksanaan pengabdian pada masyarakat dan pembahasan di atas dapat ditarik beberapa simpulan sebagai berikut :

6. Kegiatan penyuluhan telah berjalan dengan baik, peserta yang jumlahnya dibatasi karena masih berada dalam suasana pandemi Covid-19 seluruhnya hadir sesuai dengan ketentuan dari tim pengabdian kepada masyarakat.

7. Peserta secara saksama memperhatikan materi yang diberikan meskipun disampaikan dengan metode ceramah yang disertai dengan beberapa pertanyaan yang diajukan berkenaan dengan kegiatan ini.

8. Telah terbentuk sebuah lembaga peminjaman modal usaha non bank yang memperkuat kondisi sebelumnya yang telah berjalan tanpa membebankan bunga kepada peminjam modal.

9. Peserta membutuhkan modal usaha lain ketika usaha sebelumnya terhenti karen pandemi Covid dan ada yang memulai usaha baru dengan modal kepercayaan dari pemberi modal usaha.

10. Peserta penyuluhan umumnya telah menikmati dan memanfaatkan modal yang ada dan sebahagian lain belum memanfaatkan dan akan bergabung dalam lembaga yang sudah terbentuk. Hal ini sebagai wujud untuk mengembangkan usaha yang sudah ada atau memulai usaha baru dalam bentuk lembaga mikro.

11. Pengelolaan dan pengembangan modal usaha masih didasarkan pada keikhlasan, sementara implementasi dari kegiatan penyuluhan ini akan dilaksanakan ketika modal telah bertambah dan adanya pemahaman lebih lanjut tentang seluk beluk sistem mudharabah.

\section{B. Saran -saran}

Berdasarkan hasil kegiatan ini dapat diberikan saran - saran konstruktif sebagai berikut : 
Vol. 1, No. 2, Juni 2021

4. Tim harus menindaklanjuti keinginan peserta untuk memberikan pelatihan dan praktik sistem mudharabah secara khusus sehingga peserta atau masyarakat semakin tertarik untuk menjalankan usaha dengan sistem mudharabah.

5. Disarankan kepada peserta dan pengelola lembaga yang ada untuk melakukan sosialisasi pada tokoh-tokoh masyarakat tentang keberadaan lembaga yang terbentuk sehingga mendorong masyarakat untuk menanamkan modalnya pada lembaga tersebut.

6. Secara perlahan lembaga yang ada dapat dialihkan menjadi lembaga koperasi syariat berbasis masjid karena aktivitas usaha ini dimulai dari masjif.

7. Penyajian tim masih dalam bentuk ceramah, dikembangkan dalam bentuk pendidikan seperti mempraktikkan langkahlangkah memulai usaha dengan sistem mudharabah dan modal pendukungnya.

\section{DAFTAR PUSTAKA}

Asyraf Muhammad Dawabah, 2005, The Moslem Entepreneur, Kiat Sukses Pengusaha Muslim, Zikurl Hakim, Jakarta.

Burhanudin, 2013. Koperasi Syariah Dan Pengaturannya di Indonesia, UIN-Maliki Press, Malang

Farid, 2017, Kewirausahaan Syariah, Kencana, Jakarta

Hamali, Arif Yusuf dan Eka Sari Budihastuti,, 2017, Pemahaman Kewirausahaan, Kencana, Jakarta.

Husain Syahatah, Sidiq Muh Al-Amin Adh Zdhahir, 2005, Transaksi Dan Etika Bisnis Islam, Visi Insani Publishing, Jakarta.

Idri, H. 2015. Hadis Ekonomi, Ekonomi Dalam Perspektif Hadis Nabi. PrenadaMedia Group, Jakarta.

Nurhasanah, Neneng, 2015. Mudharabah dalam Teori Dan Praktek, PT. Refika Adhitama, Bandung.

Rozalinda, 2016. Fikih Ekonomi Syariah Prinsip dan Implementasinya Pada Sektor Keuangan Islam. PT. RadjaGrafindo Persada, Jakarta.

Sjahdeni, Sutan Remy, 2014. Perbanksn Syariah Produk-Produk dan Aspek-Asspek Hukumnya. Kencana Prenadamedia Group, Jakarta. 
Suryana, 2016, Kewirausahaan Kiat dan Proses Menuju Sukses, Salemba Empat, Jakarta.,

Zaidi Abdad, 2003, Lembaga Perekonomian Umat Di Dunia Islam, Anfkasa, Bandung.

Zulkifli, Sunarto. 2007. Panduan Praktis Transaksi Perbankan Syariah, Zikrul Hakim, Jakarta. 